\title{
Differences in Eating Quality Attributes between Japonica Rice from the Northeast Region and Semiglutinous Japonica Rice from the Yangtze River Delta of China
}

\author{
Ying Zhu, Dong Xu, Zhongtao Ma, Xinyi Chen, Mingyue Zhang, Chao Zhang, Guodong Liu, Haiyan Wei \\ and Hongcheng Zhang *
}

check for updates

Citation: Zhu, Y.; Xu, D.; Ma, Z.; Chen, X.; Zhang, M.; Zhang, C.; Liu, G.; Wei, H.; Zhang, H. Differences in Eating Quality Attributes between Japonica Rice from the Northeast Region and Semiglutinous Japonica Rice from the Yangtze River Delta of China. Foods 2021, 10, 2770. https:// doi.org/10.3390/foods10112770

Academic Editor: Joan M. King

Received: 25 October 2021

Accepted: 9 November 2021

Published: 11 November 2021

Publisher's Note: MDPI stays neutral with regard to jurisdictional claims in published maps and institutional affiliations.

Copyright: (c) 2021 by the authors. Licensee MDPI, Basel, Switzerland. This article is an open access article distributed under the terms and conditions of the Creative Commons Attribution (CC BY) license (https:/ / creativecommons.org/licenses/by/ $4.0 /)$.
Jiangsu Co-Innovation Center for Modern Production Technology of Grain Crops, Jiangsu Key Laboratory of Crop Genetics and Physiology, Yangzhou University, Yangzhou 225009, China; dx120180066@yzu.edu.cn (Y.Z.); dx120180065@yzu.edu.cn (D.X.); mazhongtao1106@163.com (Z.M.); cxy2215502977@163.com (X.C.); mingyue_z04@163.com (M.Z.); zc312539195@163.com (C.Z.); guodongliu@yzu.edu.cn (G.L.); hywei@yzu.edu.cn (H.W.)

* Correspondence: hczhang@yzu.edu.cn

\begin{abstract}
Differences in cooked rice and starch and protein physicochemical properties of three japonica rice were compared systematically. Cultivars of japonica rice, Daohuaxiang2, from Northeast China (NR) and two semiglutinous japonica rice (SGJR), Nangeng46 and Nangeng2728, from the Yangtze River Delta (YRD) were investigated. Both Daohuaxiang2 and Nangeng46 achieved high taste values, but there were great differences in starch and protein physicochemical properties. Daohuaxiang2 showed higher apparent amylose content (AAC), lower protein content (PC), and longer amylopectin (especially fb2 and fb3) and amylose chain lengths, resulting in thicker starch lamellae and larger starch granule size. Its cooked rice absorbed more water and expanded to larger sizes. All of these differences created a more compact gel network and harder but more elastic cooked rice for Daohuaxiang2. Nangeng46 produced a lower AAC, a higher PC, shorter amylopectin and amylose chain lengths, thinner starch lamellae, and smaller starch granule sizes, creating a looser gel network and softer cooked rice. The two SGJR, Nangeng46 and Nangeng2728, had similar low AACs but great differences in taste values. The better-tasting Nangeng46 had a lower PC (especially glutelin content) and higher proportion of amylopectin fa chains, which likely reduced the hardness, improved the appearance, and increased the adhesiveness of its cooked rice. Overall, both types of japonica rice from the NR and YRD could potentially have good eating qualities where Nangeng46's cooked rice was comparable to that of Daohuaxiang2 because of its lower AC. Moreover, its lower PC and higher proportion of amylopectin fa chains likely improved its eating quality over the inferiortasting SGJR, Nangeng2728. This research lays a foundation for the improvement of the taste of japonica rice in rice breeding.
\end{abstract}

Keywords: japonica rice; eating quality characteristics; cooked rice texture; chemical compositions; starch fine structure; starch physicochemical properties

\section{Introduction}

China is the largest japonica rice (Oryza sativa L. ssp. japonica) producer in the world, accounting for the largest planting area and the highest yield of japonica rice [1-3]. The two major japonica rice-growing regions in China, the Northeast Region (NR) and Yangtze River Delta (YRD), account for more than $80 \%$ of the japonica rice production [4]. With the rise of living standards in China, dietary structures have begun to change and a preference for high quality rice with good palatability has grown among rice consumers [5]. Rice breeders need to select varieties for traits related to preferred eating qualities.

Local environmental factors such as temperature throughout rice cultivation can affect traits related to eating quality. For example, low average daily temperature during the 
grain-filling stage of rice and significant differences in day and night temperatures [6] results in low protein content (PC) [7], amylose content (AC) of $15-20 \%$ [8], and high pasting viscosity [1] in japonica rice grown in China's NR. These desired characteristics reduce the hardness, increase the adhesiveness, and improve the sensory quality of cooked rice of grains produced in this region $[9,10]$. The higher quality of japonica rice from the NR than from the YRD [11] has increased the popularity of NR rice over YRD rice according to consumers.

Rice paddies in the YRD produced the highest yields of japonica rice in China due to large amounts of nitrogen fertilizer applied during rice growth [12]. However, greater inputs of nitrogen fertilizer elevate PCs in rice, which increases the hardness and consequently diminishes the eating quality of cooked rice [13]. The greater inputs of nitrogen fertilizer along with the frequent occurrence of high temperatures and high humidity conditions during grain filling in the YRD [14] decreased the appearance of rice grains. These constraints of poor grain appearance [15] and poor eating quality [16] restrict the market competitiveness of rice grown in the YRD.

With advancements in plant breeding technology, cultivars of semiglutinous japonica rice (SGJR) containing relatively low ACs (5-15\%) were developed [17,18]; these cultivars greatly improved the eating quality of the japonica rice from the YRD [19]. Some SGJR cultivars from YRD, such as "Nangeng46" and "Nangeng9108", won high praise in rice taste competitions many times in China and Japan, and the tastes of which were comparable to the japonica rice from the NR. Consequently, breeders have paid much more attention to SGJR, and many cultivars of SGJR are gradually becoming more commonly grown in large areas in the YRD. Many studies on SGJR have reported on some important characteristics of its starch, such as small particle size [20], high relative crystallinity [21], and high swelling power [18]. Other studies found that a low AC in SGJR with good taste quality reduced the gelatinization temperature [22] and retrogradation degree [18], increased softness of the cooked rice, and improved the cooking and eating qualities of SGJR [17].

The taste of the conventional japonica rice from NR and SGJR from YRD are similarly preferred by consumers currently [9]. Are there any differences in other eating quality characteristics between the japonica rice from the two different regions? Do all SGJR cultivars grown in the YRD have high quality in taste? Are there any differences between the different SGJR cultivars? To find answers to these questions, we compared traits from three cultivars of rice: (1) Daohuaxiang2, the most prominent high-quality japonica rice from the NR; (2) Nangeng46, the most representative SGJR from the YRD; and (3) Nangeng2728, a cultivar of SGJR from the YRD with a less desirable taste than that of the other two cultivars. The differences in cooked rice properties, flour/paste properties, chemical compositions, and starch physicochemical properties of the three japonica rice were compared systematically. The main objectives of this study were: (1) to elucidate differences in eating quality characteristics between the two good-tasting japonica rice from the NR and YRD and (2) to determine the underlying causes of potential differences in eating quality characteristics between the two SGJR cultivars. This research lays a foundation for the improvement of taste when breeding japonica rice.

\section{Materials and Methods}

\subsection{Materials}

Daohuaxiang2 was provided by Wuchang Rice Research Institute $\left(44^{\circ} 92^{\prime} \mathrm{N}, 127^{\circ} 15^{\prime} \mathrm{E}\right.$, Heilongjiang, China). This area belongs to the continental monsoon climate in a midlatitude. The annual average temperature is about $4{ }^{\circ} \mathrm{C}$ and the annual precipitation is about $625 \mathrm{~mm}$. Nangeng 46 was provided by Changshu Agricultural Science Research Institute $\left(31^{\circ} 65^{\prime} \mathrm{N}, 120^{\circ} 75^{\prime} \mathrm{E}\right.$, Suzhou, China). This area belongs to a humid subtropical monsoon climate with mild climate, four distinct seasons and abundant rainfall. The annual average temperature is about $15.7^{\circ} \mathrm{C}$ and the annual precipitation is about $1100 \mathrm{~mm}$. Nangeng2728 was provided by Huaiyin Agricultural Science Research Institute $\left(33^{\circ} 63^{\prime} \mathrm{N}\right.$, $119^{\circ} 03^{\prime} \mathrm{E}$, Huai'an, China). This area belongs to a typical transitional monsoon climate 
in the north subtropical north warm temperate zone. The annual average temperature is about $14{ }^{\circ} \mathrm{C}$ and the annual precipitation is about $960 \mathrm{~mm}$.

\subsection{Rice Taste Value}

The taste value was determined by a taste analyzer (STA1A, SATAKE, Japan) using the preset selection of "Japanese japonica rice" for the detection line and following the method described by Zhang et al. [23] with minor modifications. The taste analyzer measures the appearance of rice and other indexes by optical principle, and it synthesizes these parameters to obtain a taste value from a sample. A sample of $30 \mathrm{~g}$ of polished grains from each cultivar was placed into a stainless steel tank, washed with running purified water for $30 \mathrm{~s}$, drained, and reconstituted with purified water to bring the ratio of rice to water to 1:1.33. The sample was then soaked for $30 \mathrm{~min}$ in the tank, covered with filter paper, and sealed with a rubber ring. The stainless steel tank was placed into an electric rice cooker (JT783, Midea, Shunde, China), covered, steamed for $30 \mathrm{~min}$, and kept warm for $10 \mathrm{~min}$. The tank was taken out from the rice cooker, and the steamed rice was gently stirred and turned over. Then, the tank was covered with filter paper again and cooled for $20 \mathrm{~min}$ using a supporting air-cooling device. Afterward, the filter paper was replaced with the supporting steel cover, and the steamed rice was sealed and allowed to cool at room temperature $\left(25^{\circ} \mathrm{C}\right)$ for $90 \mathrm{~min}$. An 8-g sample of steamed rice was placed into a stainless steel ring (30-mm diameter and 9-mm height) and then pressed the rice into a cake. The rice cake was placed in a measuring tank, and the rice taste analyzer was inserted to measure appearance and taste value of the steamed rice sample. Three rice cakes were measured for each steamed rice sample, and each face (top and bottom) of each cake was measured once.

\subsection{Rice Texture Profile Analysis}

Rice hardness, springiness, stickiness, and balance value were obtained using a TA.XTPlus Texture analyzer with a P/36R probe attachment (Stable Micro Systems Ltd., Surrey, UK) and following the method described by Wang et al. [24]. The texture profile analysis simulates the experience of human mastication of rice through these specific parameters. Samples were prepared and cooked under the same conditions as described above. We also took a single grain of cooked rice from the upper, middle, and lower sections of the stainless steel tank of cooked rice and then placed the three grains of rice together on the base plate of the analyzer. The probe was set to descend at $1 \mathrm{~mm} / \mathrm{s}$, returned, and then the compression cycle was repeated. All textural analyses of each sample were replicated six times and results presented are mean values.

\subsection{Rice Cooking Properties}

The water absorption rate and volume expansion rate of rice, iodine blue value, and weight of dried solids of rice slurry were followed using the method described by Zhan et al. [25] with minor modifications. A 35-g sample of head-milled rice was placed into a stainless steel strainer after measuring its volume by the drainage method. Then, the rice was washed with tap water by panning the rice four times, then rinsing once with distilled water, and finally putting each washed sample into a 1-L beaker filled with $500 \mathrm{~mL}$ distilled water before heating. After the water boiled for $20 \mathrm{~min}$, the strainer was vertically taken off and held above the beaker of boiled liquid until any liquid from the strainer stopped dripping. The weight and volume of the cooked rice were measured. We then poured the remaining rice slurry from the beaker into a 1-L volumetric flask, allowed it to cool to room temperature, and diluted it with distilled water to $1 \mathrm{~L}$ before blending and returning the blended slurry into the original beaker. Fifty milliliters of the blended slurry was pipetted into a $100-\mathrm{mL}$ beaker, placed in an oven at $70^{\circ} \mathrm{C}$ for $24 \mathrm{~h}$, and then weighed to calculate the weight of dried solids. Ten milliliters of the blended slurry was centrifuged for $10 \mathrm{~min}$ at $8000 \mathrm{r} / \mathrm{min}$, and $1 \mathrm{~mL}$ of the supernatant was pipetted into a $100-\mathrm{mL}$ volumetric flask. We transferred $5 \mathrm{~mL}$ of $0.5-\mathrm{mol} / \mathrm{L}$ hydrochloric acid and $1 \mathrm{~mL}$ of $0.2 \mathrm{~mol} / \mathrm{L} \mathrm{I}_{2}-\mathrm{KI}$ 
solution into the flask before diluting the mixture with distilled water to the full $100 \mathrm{~mL}$. The mixture sat for $20 \mathrm{~min}$ prior to taking colorimetric measurements at $660 \mathrm{~nm}$. The water absorption rate of rice $=($ weight of cooked rice $(\mathrm{g})) /($ weight of head-milled rice $(\mathrm{g}))$ $\times 100 \%$, the volume expansion rate of rice $=($ volume of cooked rice $(\mathrm{mL})) /($ volume of head-milled rice $(\mathrm{mL})) \times 100 \%$, the weight of dried solids of rice slurry $=$ (weight of dried solids $(\mathrm{mg})) /($ weight of head-milled rice $(\mathrm{g})) \times(1000(\mathrm{~mL})) /(50(\mathrm{~mL}))$, and the iodine blue value of rice slurry was expressed as an absorbance value.

\subsection{Flour Preparation and Starch Isolation}

The milled rice was ground in a mill (FOSS 1093 Cyclotec Sample Mill, Hoganas, Sweden) and then sieved through a 100-mesh screen. Starch was isolated according to the method of Hu et al. [21].

\subsection{Rice Flour Pasting Properties}

Pasting properties of rice flour were determined using a Rapid Visco-Analyzer (RVA TecMaster, Perten, Sweden) and following the method described by Ma et al. [9]. Rice flour $(3 \mathrm{~g})$ was weighed and placed into an RVA sample canister and approximately $25 \mathrm{~mL}$ of distilled water was added so the moisture content of the rice flour totaled $12 \%$, and then the sample canister was transferred into the RVA for testing. The entire length of the program cycle was $13 \mathrm{~min}$. Starch samples cycled through a heating-cooling program starting at $50{ }^{\circ} \mathrm{C}$ for $1 \mathrm{~min}$, then increasing the heat from 50 to $95^{\circ} \mathrm{C}$ at a rate of $12^{\circ} \mathrm{C} / \mathrm{min}$, holding at $95^{\circ} \mathrm{C}$ for $2.5 \mathrm{~min}$, cooling to $50^{\circ} \mathrm{C}$ at $12{ }^{\circ} \mathrm{C} / \mathrm{min}$, and ending at another hold at $50{ }^{\circ} \mathrm{C}$ for $2 \mathrm{~min}$. The pasting parameters of peak viscosity (PV), trough viscosity (TV), breakdown $(\mathrm{BD})$, final viscosity (FV), and setback (BD) were recorded for analysis.

\subsection{Rice Flour Rheological Properties}

The freshly prepared gels of rice flour samples obtained from the RVA machine were used to obtain data on their dynamic viscoelastic properties as measured by a rheometer (Discovery HR-2, TA Instruments, New Castle, DE, USA) following the method described by Tangsrianugul et al. [26] with minor modifications and 40-mm-diameter parallel metal plates with a gap of $1000 \mu \mathrm{m}$, which was equilibrated at $25^{\circ} \mathrm{C}$. To obtain the dynamic viscoelastic measurement, the linear viscoelastic range was determined with strain sweep $(0.01-100 \%)$ at a fixed frequency of $1 \mathrm{rad} / \mathrm{s}$. After that, a dynamic frequency sweep was conducted by applying a constant strain of $5 \%$, which was within the linear region, over a frequency range of $0.1-100 \mathrm{rad} / \mathrm{s}$. The mechanical spectra were obtained by recording the dynamic moduli $G^{\prime}, G^{\prime \prime}$ and $\tan \delta$ as a function of frequency. The $G^{\prime}$ value is a measure of the dynamic elastic or storage modulus related to the material's response as a solid. The $G^{\prime \prime}$ value is a measure of the dynamic viscous or loss modulus related to the material's response as a fluid. The $\tan \delta$ value is the loss tangent defined as the ratio of $G^{\prime \prime}$ to $G^{\prime}$.

\subsection{Starch Composition}

Apparent amylose content (AAC) in rice flour was measured using the iodine colorimetric method of Tan et al. [27]. The total starch content in rice flour was determined using a total starch assay kit (Megazyme, Bray, Ireland) following the protocol described in the kit's operation manual. The following equation was used to obtain the content of amylopectin: amylopectin content $=$ total starch content-AAC.

\subsection{Isolation and Determination of Protein Components}

The albumin, globulin, prolamin, and glutelin were extracted by ultrapure water, $5 \% \mathrm{NaCl}$ solution, $70 \%$ ethyl alcohol solution, and $0.2 \% \mathrm{NaOH}$ solution, respectively, following the method described by Zheng et al. [28] with minor modifications. Rice flour $(0.2 \mathrm{~g})$ in a 10-mL centrifuge tube was oscillated with $2 \mathrm{~mL}$ ultrapure water for $2 \mathrm{~min}$ before centrifuging at $3000 \mathrm{r} / \mathrm{min}$ for $15 \mathrm{~min}$, and the supernatant which contained the albumin was collected. To fully extract as much of the remaining albumin as possible 
from the precipitate, the precipitate was mixed with $2 \mathrm{~mL}$ ultrapure water, oscillated, and centrifuged to collect the supernatant three times. The first extraction of albumin and any remaining extracted albumin were pooled together. The precipitate remaining after the albumin extraction was mixed with $2 \mathrm{~mL} 5 \% \mathrm{NaCl}$ solution to extract globulin by following the same process used to collect the albumin. The precipitate, after completing the globulin extraction, was mixed with $2 \mathrm{~mL} \mathrm{70 \%} \mathrm{ethyl} \mathrm{alcohol} \mathrm{solution,} \mathrm{oscillated} \mathrm{for}$ $2 \mathrm{~min}$, then oscillated in an $80^{\circ} \mathrm{C}$ water bath for $30 \mathrm{~min}$ with two small glass beads in a sealed tube, and then oscillated for two more minutes before centrifuging at $3000 \mathrm{r} / \mathrm{min}$ for $15 \mathrm{~min}$ to obtain the supernatant containing prolamin. This prolamin extraction process was repeated three times to extract any remaining prolamin. The precipitate remaining after the prolamin extraction was mixed with $2 \mathrm{~mL} 0.2 \% \mathrm{NaOH}$ solution to extract the glutelin by following the same process used to collect the albumin and globulin. For each cultivar's sample of rice flour, we determined its protein components using an automatic Kjeldahl apparatus (Kjeltec 8400, Foss, Denmark). Because the apparatus measures only the content of elemental nitrogen rather than the contents of proteins, the results were multiplied by 5.95 to obtain the contents of total protein and the four protein components of interest.

\subsection{Starch Molecular Size-Distributions}

The molecular size distributions of whole amylose molecules were analyzed using an Agilent 1100 series system (PSS, Mainz, Germany) equipped with a refractive index detector (RI; ShimadzuRID-10A, Shimadzu Corp., Kyoto, Japan) as described by Wang et al. [29]. Samples were separated using a GRAM precolumn and GRAM 30 and 3000 analytical columns (PSS) at a flow rate of $0.3 \mathrm{~mL} \mathrm{~min}^{-1}$. The molecular size distribution of debranched amylose were characterized using the same analytical size exclusion chromatography setup after debranching using isoamylase. Size separation of debranched starch was performed using a GRAM precolumn and GRAM 100 and 1000 analytical columns (PSS) at a flow rate of $0.6 \mathrm{~mL} \mathrm{~min}^{-1}$. Pullulan standards with peak molecular weights ranging from $342-2.35 \times 10^{6}$ were used for calibration.

\subsection{Amylopectin Fine Structure Analysis}

The fine structure of amylopectin was investigated utilizing fluorophore-assisted carbohydrate electrophoresis (FACE) as described by Li et al. [16]. First, freeze-dried debranched starch was labeled using 8-aminopyrene-1, 3, 6, trisulfonic acid (APTS) as described by Wang et al. [30]. Then, the separation of APTS-labeled debranched starch molecules was undertaken using a PA-800 Plus (Beckman-Coulter, CA, USA) FACE system equipped with an $\mathrm{N}-\mathrm{CHO}$-coated capillary and coupled with a solid-state laser-induced fluorescence detector. The carbohydrate separation buffer was used at $25^{\circ} \mathrm{C}$ at a setting of $30 \mathrm{kV}$.

\subsection{Particle Size Analysis}

The particle size distribution of starch was investigated using a laser diffraction particle size analyzer (Mastersizer 2000, Malvern, UK). About $0.2 \mathrm{~g}$ starch samples were immersed in $500 \mathrm{~mL}$ absolute ethyl alcohol and stirred at $2000 \mathrm{rpm}$. The instrument was adjusted to measure starch particle sizes ranging from 0.1 to $2000 \mu \mathrm{m}$.

\subsection{X-ray Diffraction Analysis}

$\mathrm{X}$-ray diffractograms were obtained using an X-ray powder diffractometer (D8 Advance, Bruker-AXS, Karlsruhe, Germany) operated at $200 \mathrm{~mA}$ and $40 \mathrm{kV}$, over a diffraction

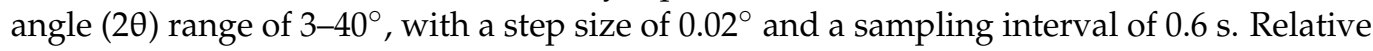
crystallinity (\%) was calculated with the MDI Jade 6 software. 


\subsection{Small-Angle X-ray Scattering (SAXS) Analysis}

The lamellar structure of starch was analyzed using a small-angle X-ray scattering instrument (Bruker NanoStar, Vantec 2000, Bruker, Germany) following the method of Yuryev et al. [31]. The SAXS data were analyzed using DIFFRACplus NanoFit software, and SAXS spectrum parameters were determined following a simple graphical method [32].

\subsection{Determination of Thermal Properties}

The thermal properties were determined using a differential scanning calorimetry (DSC) analyzer (Model 200 F3 Maia, Netzsch, Germany) according to Lu \& Lu [33]. Five milligrams of starch was mixed with water at two times the weight of the starch and then sealed in an aluminum pan at $4{ }^{\circ} \mathrm{C}$ overnight. The DSC analyzer was first calibrated using a standard pan (empty pan) as reference and then heated from $20^{\circ} \mathrm{C}$ to $100^{\circ} \mathrm{C}$ at a rate of $10^{\circ} \mathrm{C} / \mathrm{min}$. Onset temperature $\left(\mathrm{T}_{\mathrm{o}}\right)$, peak temperature $\left(\mathrm{T}_{\mathrm{p}}\right)$, conclusion temperature $\left(\mathrm{T}_{\mathrm{C}}\right)$, and gelatinization enthalpy $(\Delta \mathrm{Hg})$ were calculated by the TA Universal Analysis 2000 software. The samples were heated from $20^{\circ} \mathrm{C}$ to $100{ }^{\circ} \mathrm{C}$ at a rate of $10^{\circ} \mathrm{C} / \mathrm{min}$ and then stored at $4{ }^{\circ} \mathrm{C}$ for 7 days to determine the retrogradation properties. Retrogradation enthalpy $(\Delta \mathrm{Hr})$ was calculated by the TA Universal Analysis 2000 software, and retrogradation percentage $(\% \mathrm{R})=\Delta \mathrm{Hr} / \Delta \mathrm{Hg} \times 100 \%$.

\subsection{Statistical Analysis}

In characterizing the various parameters of rice quality, at least two replicate measurements were obtained unless otherwise specified. All data shown are means of biological repeats from three plots with standard deviations (SD). For experiments with multiple comparisons, the data were analyzed by one-way analysis of variance (ANOVA) with the least significant difference (LSD) test. Differences were determined to be statistically significant where $p<0.05$.

\section{Results}

\subsection{Cooked Rice Properties}

The taste values of Daohuaxiang2 and Nangeng46 were significantly higher than those of Nangeng 2728 (Table 1). The ranking of cultivars by the hardness of their cooked rice was Daohuaxiang2 > Nangeng2728 > Nangeng46. The hardness of Daohuaxiang2 cooked rice was $42.36 \%$ and $23.49 \%$ higher than that of Nangeng 46 and Nangeng2728, respectively. The elasticity of cooked rice for each cultivar ranked as follows: Daohuaxiang2 > Nangeng46 > Nangeng2728. The elasticity of Daohuaxiang2 was $15.07 \%$ and $19.45 \%$ higher than that of Nangeng46 and Nangeng2728, respectively. The water absorption rate and volume expansion rate of cooked rice and iodine blue value of the rice soup showed the same trend as that of the elasticity of cooked rice. The values of appearance and adhesiveness of cooked rice were both highest for Nangeng46 followed by those for Daohuaxiang2 and then those for Nangeng2728. Nangeng 46 's appearance was $6.49 \%$ and $41.38 \%$ higher, respectively, and adhesiveness was $2.06 \%$ and $2.76 \%$ higher, respectively, than those of Daohuaxiang2 and Nangeng2728. The weight of dried solids of the rice soup showed the same trend as that of appearance and adhesiveness.

Table 1. Differences of cooked rice properties among different japonica rice.

\begin{tabular}{|c|c|c|c|c|c|c|c|c|c|}
\hline \multirow{2}{*}{ Cultivar } & \multicolumn{2}{|c|}{ Taste Analyzer Properties } & \multicolumn{3}{|c|}{ Texture Properties } & \multicolumn{4}{|c|}{ Cooking Properties } \\
\hline & Taste Value & Appearance & $\begin{array}{l}\text { Hardness } \\
\text { (g) }\end{array}$ & Elasticity (\%) & $\begin{array}{l}\text { Adhesiveness } \\
\text { (g) }\end{array}$ & $\begin{array}{c}\text { Water } \\
\text { Absorption } \\
\text { Rate (\%) }\end{array}$ & $\begin{array}{l}\text { Volume } \\
\text { Expansion } \\
\text { Rate (\%) }\end{array}$ & $\begin{array}{l}\text { Iodine Blue } \\
\text { Value (A) }\end{array}$ & $\begin{array}{l}\text { Weight of } \\
\text { Dried Solids } \\
\text { (mg/g) }\end{array}$ \\
\hline Daohuaxiang2 & $80 \pm 1 \mathrm{ab}$ & $7.7 \pm 0.1 \mathrm{~b}$ & $205 \pm 4 \mathrm{a}$ & $0.565 \pm 0.003 \mathrm{a}$ & $1167 \pm 1 \mathrm{~b}$ & $391 \pm 4 \mathrm{a}$ & $532 \pm 3 a$ & $1.404 \pm 0.004 \mathrm{a}$ & $186 \pm 1 b$ \\
\hline Nangeng46 & $82 \pm 1 \mathrm{a}$ & $8.2 \pm 0.1 \mathrm{a}$ & $144 \pm 2 c$ & $0.491 \pm 0.001 \mathrm{~b}$ & $1191 \pm 1 \mathrm{a}$ & $354 \pm 3 b$ & $447 \pm 4 b$ & $0.284 \pm 0.004 b$ & $222 \pm 1 \mathrm{a}$ \\
\hline Nangeng2728 & $62 \pm 1 c$ & $5.8 \pm 0.1 \mathrm{c}$ & $166 \pm 1 b$ & $0.473 \pm 0.001 \mathrm{c}$ & $1159 \pm 2 c$ & $297 \pm 2 c$ & $375 \pm 3 c$ & $0.254 \pm 0.003 \mathrm{c}$ & $154 \pm 1 \mathrm{c}$ \\
\hline
\end{tabular}

Data are expressed as the mean $\pm \mathrm{SD}(n=3)$. Values for each index within a column followed by different lowercase letters are significantly different at the $5 \%$ probability level. 


\subsection{Rice Flour and Paste Properties}

During pasting, the highest to lowest values obtained for peak viscosity, trough viscosity and final viscosity of rice flour ranked the cultivars as Daohuaxiang2 $>$ Nangeng46 $>$ Nangeng2728 (Figure 1). The breakdown ranked the cultivars as Nangeng46 > Daohuaxiang2 > Nangeng2728 (Table 2), where the breakdown of Nangeng46 was $1.54 \%$ and $29.13 \%$ higher than that of Daohuaxiang2 and Nangeng2728, respectively. The setback values of Daohuaxiang2 were highest followed by Nangeng2728 and then Nangeng46. The setback of Daohuaxiang2 was $61.59 \%$ and $36.15 \%$ higher than that of Nangeng 46 and Nangeng2728, respectively. The pattern of consistence values was similar to the trends of the three first-order viscosity indexes, and the consistence of Daohuaxiang2 was 66.31\% and $71.53 \%$ higher than that of Nangeng46 and Nangeng2728, respectively.

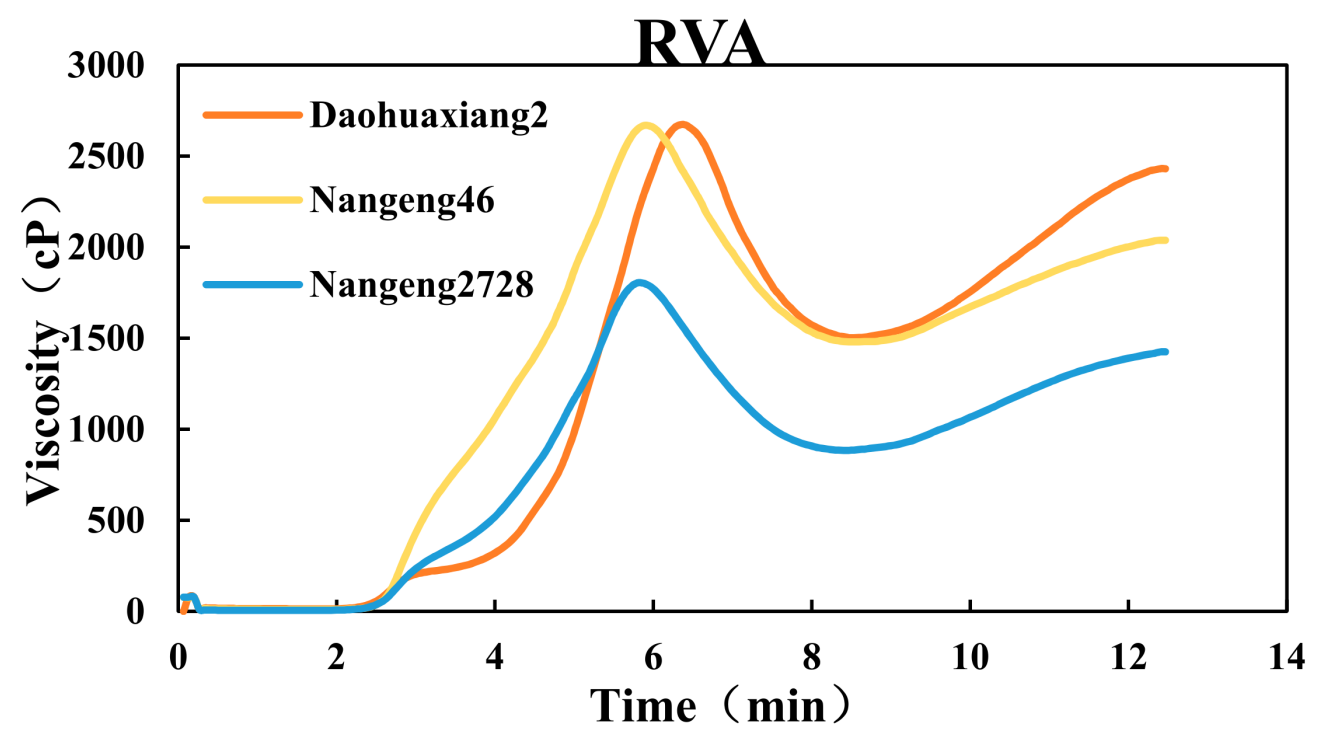

Figure 1. RVA profile of different japonica rice.

Table 2. Differences of rice flour pasting properties among different japonica rice.

\begin{tabular}{lcccccc}
\hline Cultivar & $\begin{array}{c}\text { Peak } \\
\text { Viscosity } \\
\text { (cP) }\end{array}$ & $\begin{array}{c}\text { Trough } \\
\text { Viscosity } \\
\text { (cP) }\end{array}$ & $\begin{array}{c}\text { Final } \\
\text { Viscosity } \\
\text { (cP) }\end{array}$ & $\begin{array}{c}\text { Breakdown } \\
\text { (cP) }\end{array}$ & $\begin{array}{c}\text { Setback } \\
\text { (cP) }\end{array}$ & $\begin{array}{c}\text { Consistence } \\
\text { (cP) }\end{array}$ \\
\hline Daohuaxiang2 & $2673 \pm 4 \mathrm{a}$ & $1503 \pm 3 \mathrm{a}$ & $2431 \pm 4 \mathrm{a}$ & $1170 \pm 1 \mathrm{~b}$ & $-242 \pm 1 \mathrm{a}$ & $928 \pm 1 \mathrm{a}$ \\
Nangeng46 & $2668 \pm 7 \mathrm{a}$ & $1480 \pm 5 \mathrm{~b}$ & $2038 \pm 7 \mathrm{~b}$ & $1188 \pm 2 \mathrm{a}$ & $-630 \pm 1 \mathrm{c}$ & $558 \pm 2 \mathrm{~b}$ \\
Nangeng2728 & $1804 \pm 4 \mathrm{~b}$ & $884 \pm 4 \mathrm{c}$ & $1425 \pm 6 \mathrm{c}$ & $920 \pm 1 \mathrm{c}$ & $-379 \pm 2 \mathrm{~b}$ & $541 \pm 2 \mathrm{c}$ \\
\hline
\end{tabular}

Data are expressed as the mean \pm SD $(n=3)$. Values for each index within a column followed by different lowercase letters are significantly different at the $5 \%$ probability level.

The rheological properties of rice paste were measured at $25^{\circ} \mathrm{C}$ after pasting (Figure 2). In the linear viscoelastic region and with the increase of angular frequency, the storage modulus $G^{\prime}$, loss modulus $G^{\prime \prime}$, and tan value gradually increased. During the entire dynamic frequency scanning process, both the storage modulus $G^{\prime}$ and loss modulus $G^{\prime \prime}$ values ranked the cultivars as follows: Daohuaxiang2 > Nangeng46 > Nangeng2728. The Tan value was highest in Daohuaxiang2, moderate in Nangeng46, and lowest in Nangeng2728 at the low-frequency scanning stage (angular frequency $<1 \mathrm{rad} / \mathrm{s}$ ), while the value was highest in Nangeng2728, moderate in Nangeng46, and lowest in Daohuaxiang2 at the high-frequency scanning stage (angular frequency $>10 \mathrm{rad} / \mathrm{s}$ ).

\subsection{Compositions of Starch and Protein}

The contents of total starch and apparent amylose in the cultivars ranked the cultivars in the following order: Daohuaxiang2 > Nangeng46 > Nangeng2728 (Table 3). The total starch content of Daohuaxiang2 was $3.28 \%$ and $4.76 \%$ higher than that of Nangeng 46 and Nangeng2728, respectively, and the apparent amylose content was $56.31 \%$ and $70.81 \%$ higher than that of Nangeng 46 and Nangeng2728, respectively. The ranking of cultivars by 
amylopectin content was Nangeng46 > Nangeng2728 > Daohuaxiang2. The amylopectin content of Nangeng 46 was $3.55 \%$ and $0.53 \%$ higher than that of Daohuaxiang2 and Nangeng2728, respectively. The hierarchical orders of cultivars based on highest to lowest contents of total protein and glutelin were both Nangeng2728 $>$ Nangeng46 $>$ Daohuaxiang2. The contents of total protein and of the four types of protein components (Table 3) of Daohuaxiang2 were significantly lower than those of Nangeng46 and Nangeng2728. There were no significant differences in contents of albumin, globulin, and prolamin between Nangeng46 and Nangeng2728.
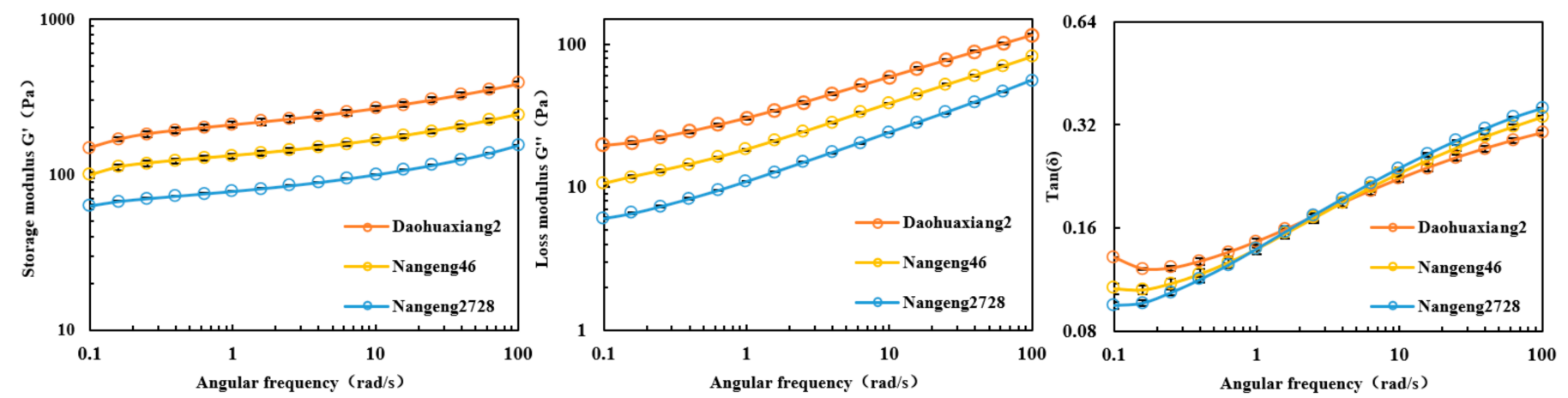

Figure 2. Rheological properties of different japonica rice.

Table 3. Differences of chemical components among different japonica rice.

\begin{tabular}{|c|c|c|c|c|c|c|c|c|}
\hline \multirow[b]{2}{*}{ Cultivar } & \multicolumn{3}{|c|}{ Starch Components (\%) } & \multicolumn{5}{|c|}{ Protein Components (\%) } \\
\hline & $\begin{array}{l}\text { Total Starch } \\
\text { Content }\end{array}$ & AAC & $\begin{array}{l}\text { Amylopectin } \\
\text { Content }\end{array}$ & $\begin{array}{l}\text { Total Protein } \\
\text { Content }\end{array}$ & $\begin{array}{l}\text { Albumin } \\
\text { Content }\end{array}$ & $\begin{array}{l}\text { Globulin } \\
\text { Content }\end{array}$ & $\begin{array}{c}\text { Prolamin } \\
\text { Content }\end{array}$ & $\begin{array}{l}\text { Glutelin } \\
\text { Content }\end{array}$ \\
\hline Daohuaxiang2 & $88.92 \pm 0.06 \mathrm{a}$ & $15.10 \pm 0.11 \mathrm{a}$ & $73.80 \pm 0.17 c$ & $6.39 \pm 0.06 c$ & $0.49 \pm 0.01 b$ & $0.64 \pm 0.03 b$ & $0.96 \pm 0.02 b$ & $3.44 \pm 0.04 \mathrm{c}$ \\
\hline Nangeng46 & $86.10 \pm 0.07 \mathrm{~b}$ & $9.66 \pm 0.09 \mathrm{~b}$ & $76.42 \pm 0.05 a$ & $7.21 \pm 0.05 \mathrm{~b}$ & $0.58 \pm 0.03 \mathrm{a}$ & $0.80 \pm 0.02 \mathrm{a}$ & $1.09 \pm 0.01 \mathrm{a}$ & $3.62 \pm 0.05 b$ \\
\hline Nangeng2728 & $84.88 \pm 0.04 \mathrm{c}$ & $8.84 \pm 0.10 \mathrm{c}$ & $76.02 \pm 0.05 b$ & $7.84 \pm 0.06 \mathrm{a}$ & $0.56 \pm 0.01 \mathrm{a}$ & $0.76 \pm 0.02 \mathrm{a}$ & $1.12 \pm 0.02 \mathrm{a}$ & $4.33 \pm 0.03 \mathrm{a}$ \\
\hline
\end{tabular}

Data are expressed as the mean $\pm \mathrm{SD}(n=3)$. Values for each index within a column followed by different lowercase letters are significantly different at the $5 \%$ probability level. AAC, apparent amylose content.

\subsection{Fine Structure of Starch}

The molecular weights of total starch, amylose, and amylopectin of Daohuaxiang2 were significantly higher than those of Nangeng46 and Nangeng2728 (Table 4). The molecular weight of total starch for Dahuaxiang2 was $57.28 \%$ and $76.88 \%$ higher, the amylose molecular weight was $9.69 \%$ and $9.31 \%$ higher, and the amylopectin molecular weight was $72.78 \%$ and $89.70 \%$ higher than those of Nangeng 46 and Nangeng2728, respectively. There was no significant difference in amylose molecular weight between Nangeng 46 and Nangeng2728.

The $100<X \leq 1000$ amylose chain proportion of Dahuaxiang2 was $35.14 \%$ and $35.14 \%$ higher than that of Nangeng46 and Nangeng2728, respectively. There was no significant difference in $100<X \leq 1000$ amylose chain length proportion between Nangeng46 and Nangeng2728. The $1000<X \leq 2000$ and $2000<X \leq 20000$ amylose chain proportions from highest to lowest among the cultivars were Daohuaxiang2 > Nangeng46 $>$ Nangeng2728. The $1000<X \leq 2000$ amylose chain proportion of Daohuaxiang2 was $81.76 \%$ and $149.19 \%$ higher and the $2000<X \leq 20000$ amylose chain proportion was $64.26 \%$ and $139.27 \%$ higher than that of Nangeng46 and Nangeng2728, respectively. 
Table 4. Differences of molecular weight and chain length distribution of starch among different japonica rice.

\begin{tabular}{|c|c|c|c|c|c|c|c|c|c|c|c|}
\hline \multirow[b]{2}{*}{ Cultivar } & \multicolumn{3}{|c|}{ Molecular Weight (Da) } & \multicolumn{3}{|c|}{ Chain Length Proportion of Amylose (\%) } & \multicolumn{5}{|c|}{ Chain Length Proportion of Amylopectin (\%) } \\
\hline & Total Starch & Amylose & Amylopectin & $100<X \leq 1000$ & $1000<X \leq 2000$ & $2000<X \leq 20,000$ & Fa (DP6-12) & Fb1 (DP13-24) & Fb2 (DP25-36) & Fb3 (DP37-100) & $\begin{array}{l}\text { Average Chain } \\
\text { Length }\end{array}$ \\
\hline Daohuaxiang2 & $3493860 \pm 9468 \mathrm{a}$ & $183319 \pm 566 \mathrm{a}$ & $5341014 \pm 5658 \mathrm{a}$ & $6.23 \pm 0.11 \mathrm{a}$ & $3.09 \pm 0.03 \mathrm{a}$ & $5.24 \pm 0.05 \mathrm{a}$ & $28.00 \pm 0.04 \mathrm{~b}$ & $44.12 \pm 0.01 \mathrm{c}$ & $11.92 \pm 0.03 \mathrm{a}$ & $15.96 \pm 0.03 \mathrm{a}$ & $21.87 \pm 0.04 \mathrm{a}$ \\
\hline Nangeng46 & $2221393 \pm 7797 \mathrm{~b}$ & $167127 \pm 366 \mathrm{~b}$ & $3091176 \pm 5284 b$ & $4.61 \pm 0.03 \mathrm{~b}$ & $1.70 \pm 0.02 \mathrm{~b}$ & $3.19 \pm 0.02 \mathrm{~b}$ & $30.49 \pm 0.02 \mathrm{a}$ & $45.25 \pm 0.03 \mathrm{~b}$ & $11.65 \pm 0.02 \mathrm{~b}$ & $12.61 \pm 0.03 \mathrm{c}$ & $20.15 \pm 0.04 \mathrm{c}$ \\
\hline Nangeng2728 & $1975251 \pm 6772 \mathrm{c}$ & $167713 \pm 713 b$ & $2815500 \pm 5335 c$ & $4.61 \pm 0.01 \mathrm{~b}$ & $1.24 \pm 0.04 \mathrm{c}$ & $2.19 \pm 0.02 c$ & $24.40 \pm 0.01 \mathrm{c}$ & $49.45 \pm 0.01 \mathrm{a}$ & $11.65 \pm 0.01 \mathrm{~b}$ & $14.50 \pm 0.01 \mathrm{~b}$ & $21.34 \pm 0.01 \mathrm{~b}$ \\
\hline
\end{tabular}

Data are expressed as the mean \pm SD $(n=3)$. Values for each index within a column followed by different lowercase letters are significantly different at the $5 \%$ probability level. 
The fa chain (DP6-12) proportion of amylopectin was highest in Nangeng46, then in Daohuaxiang2, and lowest in Nangeng2728. The fa chain (DP6-12) proportion of amylopectin of Nangeng 46 was $8.89 \%$ and $24.96 \%$ higher than that of Daohuaxiang2 and Nangeng2728, respectively. The fb1 chain (DP13-24) proportion of amylopectin among cultivars ranked as follows: Nangeng2728 > Nangeng46 > Daohuaxiang2. The $\mathrm{fb} 1$ chain (DP13-24) proportion of amylopectin of Nangeng2728 was $12.08 \%$ and $9.28 \%$ higher than that of Daohuaxiang2 and Nangeng46, respectively. The fb2 chain (DP25-36) proportion of amylopectin of Daohuaxiang2 was 2.32\% and 2.32\% higher than that of Nangeng 46 and Nangeng2728, respectively. There was no significant difference in fb2 chain (DP25-36) proportion of amylopectin between Nangeng 46 and Nangeng2728. The fb3 chain (DP37-100) proportion and average chain length of amylopectin placed the cultivars in the following order: Daohuaxiang2 > Nangeng2728 > Nangeng46. The fb3 chain (DP37-100) proportion of Daohuaxiang2 was $26.57 \%$ and $10.07 \%$ higher and the average chain length was $8.54 \%$ and $2.48 \%$ higher than those of Nangeng 46 and Nangeng 2728 , respectively.

\subsection{Physicochemical Properties of Starch}

Nangeng46 produced the highest proportion of small starch particles $(0-3 \mu \mathrm{m})$, while Daohuaxiang2 produced the highest proportion of large starch particles ( $>6 \mu \mathrm{m})$ (Figure 3). The average volume and average surface area of starch particles were greatest in Daohuaxiang2, moderate in Nangeng2728, and lowest in Nangeng46 (Table 5). The average volume of particles in Daohuaxiang2 was $22.88 \%$ and $20.16 \%$ higher than that in Nangeng 46 and Nangeng2728, respectively, and average surface area of particles was $24.77 \%$ and $20.12 \%$ higher, respectively. The proportions of $0-2-\mu \mathrm{m}$ diameter and $2-4-\mu \mathrm{m}$ diameter particles placed the cultivars in the following order: Nangeng46 > Nangeng2728 > Daohuaxiang2. The order of cultivars by the proportion of 4-6- $\mu \mathrm{m}$ diameter particles was Nangeng2728 $>$ Daohuaxiang2 > Nangeng46. From highest to lowest proportions of the 6-8- $\mu \mathrm{m}$ diameter and 8-14- $\mu \mathrm{m}$ diameter particles, the cultivars ranked as follows: Daohuaxiang2 > Nangeng2728 > Nangeng46.

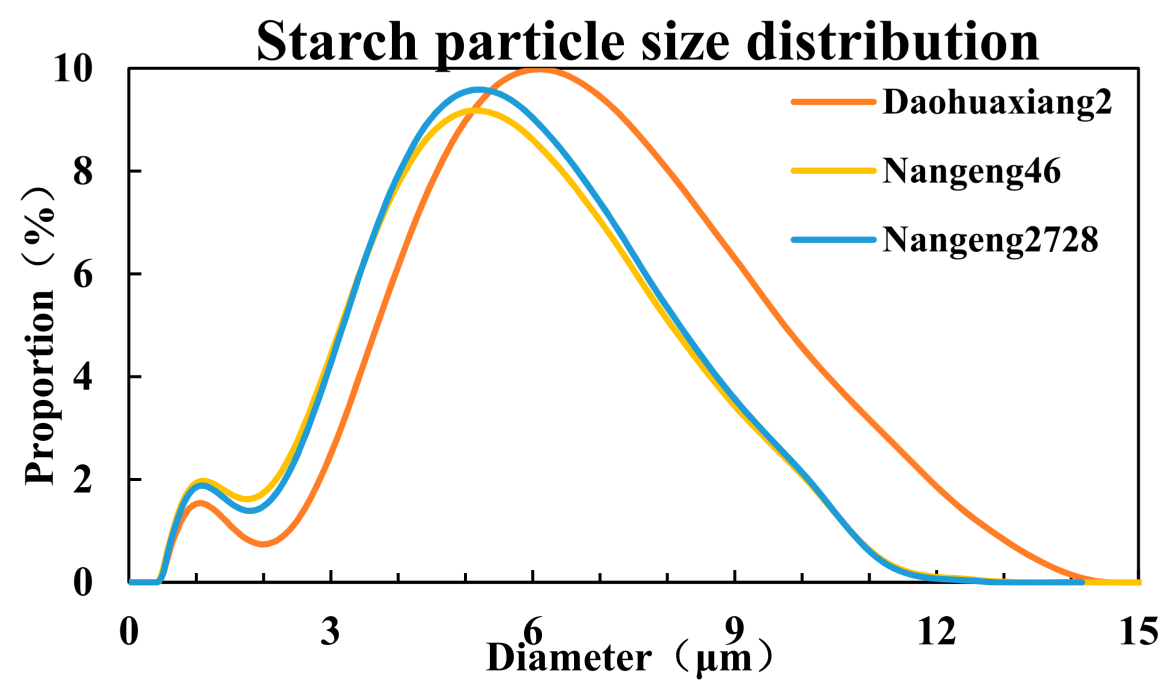

Figure 3. Starch particle size distribution of different japonica rice.

Table 5. Differences of starch particle size distribution among different japonica rice.

\begin{tabular}{|c|c|c|c|c|c|c|c|}
\hline Cultivar & $\begin{array}{l}\text { Average } \\
\text { Volume }\end{array}$ & $\begin{array}{c}\text { Average } \\
\text { Surface Area }\end{array}$ & $0 \sim 2 \mu \mathrm{m}$ & $2 \sim 4 \mu \mathrm{m}$ & $4 \sim 6 \mu \mathrm{m}$ & $6 \sim 8 \mu \mathrm{m}$ & $8 \sim 14 \mu \mathrm{m}$ \\
\hline Daohuaxiang2 & $5.853 \pm 0.001 \mathrm{a}$ & $3.707 \pm 0.001 \mathrm{a}$ & $11.45 \pm 0.01 \mathrm{c}$ & $20.15 \pm 0.01 c$ & $27.27 \pm 0.01 \mathrm{~b}$ & $26.84 \pm 0.01 \mathrm{a}$ & $14.34 \pm 0.01 \mathrm{a}$ \\
\hline Nangeng46 & $4.763 \pm 0.001 c$ & $2.971 \pm 0.001 \mathrm{c}$ & $18.98 \pm 0.01 \mathrm{a}$ & $27.94 \pm 0.01 \mathrm{a}$ & $26.85 \pm 0.01 \mathrm{c}$ & $20.20 \pm 0.01 c$ & $6.03 \pm 0.01 c$ \\
\hline Nangeng2728 & $4.871 \pm 0.001 \mathrm{~b}$ & $3.086 \pm 0.001 \mathrm{~b}$ & $17.41 \pm 0.01 \mathrm{~b}$ & $27.27 \pm 0.02 b$ & $27.97 \pm 0.01 \mathrm{a}$ & $21.19 \pm 0.01 \mathrm{~b}$ & $6.16 \pm 0.01 b$ \\
\hline
\end{tabular}

Data are expressed as the mean $\pm \mathrm{SD}(n=3)$. Values for each index within a column followed by different lowercase letters are significantly different at the $5 \%$ probability level. 
Cultivar rankings by peak intensity and relative crystallinity of starch were Nangeng2728 > Nangeng46 > Daohuaxiang2 (Table 6). The peak intensity of Nangeng2728 was $143.44 \%$ and $20.42 \%$ higher than that of Daohuaxiang2 and Nangeng46, respectively, and the relative crystallinity was $24.37 \%$ and $3.78 \%$ higher, respectively. The lamellar thickness of starch put the cultivars in the order of Daohuaxiang2 > Nangeng46 > Nangeng2728, where thickness of Daohuaxiang2 was 3.63\% and 8.15\% higher than that of Nangeng46 and Nangeng2728, respectively.

Table 6. Differences of starch crystal structure and thermal properties among different japonica rice.

\begin{tabular}{|c|c|c|c|c|c|c|c|c|c|}
\hline \multirow[b]{2}{*}{ Cultivar } & \multicolumn{3}{|c|}{ Crystal Structure of Starch } & \multicolumn{6}{|c|}{ Thermal Properties } \\
\hline & $\begin{array}{c}\text { Peak } \\
\text { Intensity } \\
\text { (Counts) }\end{array}$ & $\begin{array}{c}\text { Lamellar } \\
\text { Thickness } \\
\text { (nm) }\end{array}$ & $\begin{array}{c}\text { Relative } \\
\text { Crystallinity } \\
(\%)\end{array}$ & $\mathrm{T}_{\mathrm{o}}\left({ }^{\circ} \mathrm{C}\right)$ & $\mathrm{T}_{\mathrm{p}}\left({ }^{\circ} \mathrm{C}\right)$ & $\mathrm{T}_{\mathrm{c}}\left({ }^{\circ} \mathrm{C}\right)$ & $\Delta \mathrm{Hg}(\mathrm{J} / \mathrm{g})$ & $\Delta \mathrm{Hr}(\mathrm{J} / \mathrm{g})$ & $\% R(\%)$ \\
\hline Daohuaxiang2 & $87.7 \pm 1.3 c$ & $9.42 \pm 0.02 \mathrm{a}$ & $28.68 \pm 0.15 c$ & $59.0 \pm 0.2 \mathrm{~b}$ & $63.3 \pm 0.1 \mathrm{c}$ & $69.0 \pm 0.1 \mathrm{c}$ & $9.60 \pm 0.04 c$ & $3.49 \pm 0.02 b$ & $36.39 \pm 0.13 b$ \\
\hline Nangeng46 & $177.3 \pm 0.1 \mathrm{~b}$ & $9.09 \pm 0.05 b$ & $34.37 \pm 0.28 b$ & $59.2 \pm 0.1 b$ & $63.7 \pm 0.1 \mathrm{~b}$ & $71.1 \pm 0.1 \mathrm{~b}$ & $12.60 \pm 0.12 b$ & $2.49 \pm 0.02 c$ & $19.79 \pm 0.02 c$ \\
\hline Nangeng2728 & $213.5 \pm 1.1 \mathrm{a}$ & $8.71 \pm 0.01 \mathrm{c}$ & $35.67 \pm 0.07 \mathrm{a}$ & $62.9 \pm 0.1 \mathrm{a}$ & $76.6 \pm 0.1 \mathrm{a}$ & $84.7 \pm 0.2 \mathrm{a}$ & $16.85 \pm 0.07 \mathrm{a}$ & $7.64 \pm 0.02 \mathrm{a}$ & $45.34 \pm 0.29 \mathrm{a}$ \\
\hline
\end{tabular}

Data are expressed as the mean $\pm \mathrm{SD}(n=3)$. Values for each index within a column followed by different lowercase letters are significantly different at the $5 \%$ probability level. $\mathrm{T}_{\mathrm{o}}$, onset temperature; $\mathrm{T}_{\mathrm{p}}$, peak temperature; $\mathrm{T}_{\mathrm{c}}$, conclusion temperature; $\Delta \mathrm{Hg}$, gelatinization enthalpy; $\Delta \mathrm{Hr}$, retrogradation enthalpy; $\% \mathrm{R}$, retrogradation percentage.

The greatest to lowest values of each, $\mathrm{T}_{\mathrm{o}}, \mathrm{T}_{\mathrm{p}}, \mathrm{T}_{\mathrm{c}}$, and $\Delta \mathrm{Hg}$, ranked the three cultivars as Nangeng2728 > Nangeng46 > Daohuaxiang2. When comparing values of Nangeng2728 to those of Daohuaxiang2 and Nangeng $46, \mathrm{~T}_{\mathrm{o}}$ was $6.61 \%$ and $6.25 \%$ higher, $\mathrm{T}_{\mathrm{p}}$ was $21.01 \%$ and $20.25 \%$ higher, $\mathrm{T}_{\mathrm{c}}$ was $22.75 \%$ and $19.13 \%$ higher, and $\Delta \mathrm{Hg}$ was $75.52 \%$ and $33.73 \%$ higher, respectively. The regeneration degree of starch was tested after 7 days, and the retrogradation enthalpy $(\Delta \mathrm{Hr})$ and retrogradation percentage $(\% \mathrm{R})$ placed the cultivars in the following order: Nangeng2728 > Nangeng46 > Daohuaxiang2. The $\Delta \mathrm{Hr}$ of Nangeng 2728 was $118.91 \%$ and $206.83 \%$ higher than that of Daohuaxinag2 and Nangeng 46, respectively, and the \%R was $24.59 \%$ and $129.11 \%$ higher than that of Daohuaxinag2 and Nangeng 46, respectively.

\section{Discussion}

\subsection{Mechanisms Underlying a Good Quality of Taste of Japonica Rice from the NR and YRD in China}

Japonica rice grown in the NR and YRD, such as Daohuaxiang2 and Nangeng46, respectively, had excellent quality of taste (Table 1) and is popular with consumers [4]. The taste quality of cooked rice is a complex trait attributed to numerous factors [34,35]. Starch and protein are two major components in the endosperm of rice, the physicochemical properties of which affect the taste quality of cooked rice. Starch is a branched glucose polymer that usually is composed of two types of molecules: amylose and amylopectin [36]. Amylopectin chains are packed into a crystalline lattice within the lamellae of a starch granule and form crystalline layers [37]. Long amylopectin chains (especially fb2 and fb3 chains) could increases the thickness of the lamellae by passing from the crystalline region into the amorphous region of the lamellae [38,39]. When they pass among the lamellae, they increase the size of the starch granule [40]. During rice cooking, a larger starch granule size can result in greater absorption of water and swelling to a larger volume, which influences the viscoelastic properties of rice [41]. Large amounts of amylopectin and small amounts of amylose that dissolve from rice grains [42,43] gradually cover the surfaces of rice grains and form a thin film [44]. This film plays a crucial role in the appearance and adhesiveness of cooked rice [45].

As the second most abundant constituent of milled rice after starch, proteins will increase the hardness of cooked rice as past studies have reported [46,47]. Additionally, proteins have been suggested to play a role in rice quality by interacting with starch. Proteins (especially glutelin) often inhibit starch granules from absorbing water and swelling, which affects the elasticity of cooked rice. Proteins are more likely to combine with amylose during recrystallization, which results in more protein-amylose complexes filling the pores 
of the gel network, thus increasing the hardness of the gel and the cooked rice $[48,49]$. In our study, Daohuaxiang2 showed both longer lengths of amylopectin (especially fb2 and $\mathrm{fb} 3$ chain lengths) and amylose chains than Nangeng46, resulting in thicker starch lamellae, larger starch granule sizes [40], and a firmer double helix structure, which ultimately creates a more compact gel network and harder cooked rice [8,50]. Furthermore, the lower PC in Daohuaxiang2 than in Nangeng46 led to a smaller effect of proteins inhibiting starch granules from absorbing water and swelling during cooking. Thus, the cooked rice of Daohuaxiang2 absorbed more water and expanded to larger sizes than that of Nangeng46 (Table 1). Due to these factors, Daohuaxiang2 showed higher elasticity in its cooked rice, which improved its taste [25,51]. Despite the fact that proteins increase the hardness of cooked rice and that Nangeng46 had a higher PC than Daohuaxiang2, the gel network and cooked rice of Nangeng46 was softer than that of Daohuaxiang2 (Figure 2, Table 1). This was probably due to significant differences in AC and chain lengths of amylose and amylopectin between the two types of japonica rice. High AC and long chain lengths of amylose and amylopectin thus played a decisive role in the hardness of the gel network and cooked rice, regardless of PC. As a result, the cooked rice of Daohuaxiang2 was harder and the cooked rice of Nangeng46 was softer in texture.

\subsection{Differences in Eating Quality Characteristics between Two SGJR Cultivars}

Relatively low AC and a soft-texture in cooked rice are the most noticeable features reported of SGJR [19]. Although Nangeng 46 and Nangeng2728 produced similarly low ACs (Table 3), there were great differences in cooked rice properties between the two SGJR cultivars. Of rice with similar ACs, proteins have been shown to play an important role in the hardness of cooked rice [52]. Thus, the higher PC of Nangeng2728 increased the hardness of its cooked rice compared to that of Nangeng46 (Figure 2). Consistence measured by RVA and \%R determined by DSC can both be used to indicate the retrogradation of starch. In our study, the results showed that consistence of Nangeng46 was higher than that of Nangeng2728 (Table 2), while \%R of Nangeng46 was lower than that of Nangeng2728 (Table 5). In fact, the consistence measured by RVA reflected the short-term retrogradation of starch, which is mainly related to the rapid recrystallization of amylose [8]. The $\% \mathrm{R}$ determined by DSC reflected the long-term retrogradation of starch, which not only was related to the rapid recrystallization of amylose, but also to the recrystallization of amylopectin [53]. Nangeng2728 had a lower measure of consistence than Nangeng 46 due to the former's lower content and shorter chain length of amylose. The \%R of Nangeng2728 was larger than that of Nangeng46 due to the larger proportion of long chain lengths of amylopectin [54]. The recrystallization of amylopectin increased gel hardness and further increased the hardness of cooked rice. In addition, Nangeng46 had a larger proportion of amylopectin fa chains than Nangeng2728. A recent study reported that short chain lengths of amylopectin are easier to dissolve than long chain lengths of amylopectin [55]. Moreover, Nangeng 46 had a higher iodine blue value for its rice soup, indicating that more amylose was dissolved while cooking this rice [45]. Consequently, Nangeng46 had a higher dry matter weight of rice soup, which was attributed to the greater amounts of dissolved amylopectin and amylose. The dissolution of these two types of starch thickened the film on the surface of cooked rice grains and ultimately improved the appearance and increased the adhesiveness of the cooked rice.

\section{Conclusions}

Starch and protein physicochemical properties are of great necessity in improving the taste of japonica rice in future. The critical point lies in the fact of achieving a balance of hardness, softness, adhesiveness and elasticity of cooked rice.

Nangeng46 and Nangeng2728, the two SGJR that are cultivated in the YRD and had lower ACs than the AC of rice from the NR, presented great differences in eating quality between them. Reducing PC (especially glutelin content) and increasing the proportion of amylopectin fa chains can improve the eating quality of SGJR from the YRD. Between the 
two types of YRD rice, Nangeng46, with its lower PCs (especially glutelin content) and higher proportion of amylopectin fa chains, is the better rice based on appearance and adhesiveness, lower hardness and higher taste value.

Japonica rice produced in both the NR and YRD can have good eating qualities. Daohuaxiang2, the more widely-preferred japonica rice that is produced in the NR, exhibited harder but more elastic cooked rice. Nangeng46, a SGJR from the YRD, exhibited a softer texture of cooked rice because of its lower AC. Therefore, as long as a balance of hardness, softness, adhesiveness and elasticity is achieved in cultivars of rice, the cooked grains are expected to have excellent taste irrespective of the amylose and protein contents and other physicochemical properties.

Author Contributions: Conceptualization, H.W.; methodology, H.Z.; software, Y.Z.; validation, Y.Z. and H.W.; formal analysis, Y.Z.; investigation, Y.Z.; resources, H.W. and H.Z.; data curation, Y.Z., Z.M., X.C., M.Z. and C.Z.; writing-original draft preparation, Y.Z. and D.X.; writing-review and editing, Y.Z.; visualization, Y.Z.; supervision, G.L.; project administration, H.W.; funding acquisition, H.W. All authors have read and agreed to the published version of the manuscript.

Funding: This research was funded by the National Natural Science Foundation of China (grant number 31971841); Pilot Project of National Cooperative Promotion Plan of Major Agricultural Technologies (2020-SJ-047-04-01); Earmarked Fund for Jiangsu Agricultural Industry Technology System, China (grant number JATS[2020]450); National Rice Industry Technology System (grant number CARS0127); and Project Funded by the Priority Academic Program Development of Jiangsu Higher Education Institutions, China.

Data Availability Statement: Not applicable.

Acknowledgments: We fully appreciate the editors and all anonymous reviewers for their constructive comments on this manuscript.

Conflicts of Interest: The authors declare no conflict of interest. The funders had no role in the design of the study; in the collection, analyses, or interpretation of data; in the writing of the manuscript, or in the decision to publish the results.

\section{References}

1. Nakamura, S.; Cui, J.; Zhang, X.; Yang, F.; Xu, X.; Sheng, H.; Ohtsubo, K.I. Comparison of eating quality and physicochemical properties between Japanese and Chinese rice cultivars. Biosci. Biotech. Biochem. 2016, 80, 1-13. [CrossRef] [PubMed]

2. Peng, S.B.; Tang, Q.Y.; Zou, Y.B. Current Status and Challenges of Rice Production in China. Plant. Prod. Sci. 2008, 12, 3-8. [CrossRef]

3. Sun, M.; Abdula, S.E.; Lee, H.; Cho, Y.; Han, L.; Koh, H.; Cho, Y. Molecular Aspect of Good Eating Quality Formation in Japonica Rice. PLoS ONE 2013, 6, e18385. [CrossRef] [PubMed]

4. Yang, X.Y.; Lin, Z.M.; Liu, Z.H.; Ajim, M.A.; Bi, J.G.; Li, G.H.; Wang, Q.S.; Wang, S.H.; Ding, Y.F. Physicochemical and Sensory Properties of japonica Rice Varied with Production Areas in China. J. Integr. Agric. 2013, 12, 1748-1756. [CrossRef]

5. Bao, J.; Kong, X.; Xie, J.; Xu, L. Analysis of genotypic and environmental effects on rice starch. 1. Apparent amylose content, pasting viscosity, and gel texture. J. Agric. Food Chem. 2004, 52, 6010-6016. [CrossRef]

6. Xu, Y.J.; Ying, Y.N.; Ouyang, S.H.; Duan, X.L.; Sun, H.; Jiang, S.K.; Sun, S.C.; Bao, J.S. Factors Affecting Sensory Quality of Cooked japonica Rice. Rice Sci. 2018, 25, 330-339.

7. He, G.S.; Wang, H.Z.; Cheng, X.Y.; Ma, Z.B.; Liu, D.; Quan, C.; Lv, Y.D.; Xu, Z.J. Comparative study on rice quality traits in different ages in three northeastern provinces. Heilongjiang Agric. Sci. 2011, 8, 5-10. (In Chinese)

8. Yu, S.F.; Ma, Y.; Sun, D.W. Impact of amylose content on starch retrogradation and texture of cooked milled rice during storage. J. Cereal Sci. 2009, 50, 139-144. [CrossRef]

9. Ma, H.Z.; Chen, X.Y.; Wang, Z.J.; Zhu, Y.; Jiang, W.Q.; Ren, G.L.; Ma, Z.T.; Wei, H.Y.; Zhang, H.C.; Liu, G.D. Analysis on Appearance and Cooking Taste Quality Characteristics of Some High Quality Japonica Rice in China. Sci. Agric. Sin. 2021, 54, 1338-1353. (In Chinese)

10. Chen, Z.F. The Difference of Yield and Quality of Japonica Rice between North and South China. Master's Thesis, Yangzhou University, Yangzhou, China, 2020. (In Chinese).

11. Xu, Z.J.; Han, Y.; Shao, G.J.; Zhang, X.J.; Quan, C.Z.; Pan, G.J.; Yan, P.; Chen, W.F. Comparison of Rice Quality Characters in Northeast Region of China. Chin. J. Rice Sci. 2010, 24, 531-534. (In Chinese)

12. Peng, S.B.; Buresh, R.J.; Huang, J.L.; Yang, J.C.; Zou, Y.B.; Zhong, X.H.; Wang, G.H.; Zhang, F.S. Strategies for overcoming low agronomic nitrogen use efficiency in irrigated rice systems in China. Field Crop. Res. 2006, 96, 37-47. [CrossRef] 
13. Gu, J.F.; Chen, J.; Chen, L.; Wang, Z.Q.; Zhang, H.; Yang, J.C. Grain quality changes and responses to nitrogen fertilizer of japonica rice cultivars released in the Yangtze River Basin from the 1950s to 2000s. Crop. J. 2015, 3, 285-297. [CrossRef]

14. Deng, N.Y.; Ling, X.X.; Sun, Y.; Zhang, C.D.; Fahad, S.; Peng, S.B.; Cui, K.H.; Nie, L.X.; Huang, J.L. Influence of temperature and solar radiation on grain yield and quality in irrigated rice system. Eur. J. Agron. 2015, 64, 37-46. [CrossRef]

15. Wani, A.A.; Singh, P.; Shah, M.A.; Schweiggert-Weisz, U.; Gul, K.; Wani, I.A. Rice Starch Diversity: Effects on Structural, Morphological, Thermal, and Physicochemical Properties-A Review. Compr. Rev. Food Sci. F. 2012, 11, 417-436. [CrossRef]

16. Li, H.; Prakash, S.; Nicholson, T.M.; Fitzgerald, M.A.; Gilbert, R.G. The importance of amylose and amylopectin fine structure for textural properties of cooked rice grains. Food Chem. 2016, 196, 702-711. [CrossRef] [PubMed]

17. Yu, H.X.; Liu, Q.Q.; Xu, L.; Lu, M.F.; Cai, X.L.; Gong, Z.Y.; Yi, C.D.; Wang, Z.Y.; Gu, M.H. Breeding and Field Performance of Novel Soft and Waxy Transgenic Rice Lines Without Selectable Marker. Acta Agron. Sin. 2009, 35, 967-973.

18. Xu, Z.H.; Yu, M.M.; Yin, Y.W.; Zhu, C.W.; Ji, W. Generation of selectable marker-free soft transgenic rice with transparent kernels by downregulation of SSSII-2. Crop. J. 2020, 8, 57-65. [CrossRef]

19. Bian, J.L.; Xu, F.F.; Han, C.; Qiu, S.; Ge, J.L.; Xu, J.; Zhang, H.C.; Wei, H.Y. Effects of planting methods on yield and quality of different types of japonica rice in northern Jiangsu plain, China. J. Integr. Agric. 2018, 17, 2624-2635. [CrossRef]

20. Zhu, D.W.; Zhang, H.C.; Guo, B.W.; Xu, K.; Dai, Q.G.; Wei, C.X.; Zhou, G.S.; Huo, Z.Y. Effects of nitrogen level on structure and physicochemical properties of rice starch. Food Hydrocoll. 2017, 63, 525-532. [CrossRef]

21. Hu, Q.; Liu, Q.Y.; Jiang, W.Q.; Qiu, S.; Wei, H.Y.; Zhang, H.C.; Liu, G.D.; Xing, Z.P.; Hu, Y.J.; Guo, B.W. Effects of mid-stage nitrogen application timing on the morphological structure and physicochemical properties of Japonica rice starch. J. Sci. Food Agric. 2020, 101, 2463-2471. [CrossRef] [PubMed]

22. Hu, Y.J.; Li, L.; Tian, J.Y.; Zhang, C.X.; Wang, J.; Yu, E.W.; Xing, Z.P.; Guo, B.W.; Wei, H.Y.; Huo, Z.Y.; et al. Effects of dynamic low temperature during the grain filling stage on starch morphological structure, physicochemical properties, and eating quality of soft japonica rice. Cereal Chem. 2020, 97, 540-550. [CrossRef]

23. Zhang, X.C.; Fu, L.B.; Tu, Y.S.; Zhao, H.F.; Kuang, L.H.; Zhang, G.P. The Influence of Nitrogen Application Level on Eating Quality of the Two Indica-Japonica Hybrid Rice Cultivars. Plants 2002, 9, 1663. [CrossRef] [PubMed]

24. Wang, W.T.; Ge, J.L.; Xu, K.; Gao, H.; Liu, G.D.; Wei, H.Y.; Zhang, H.C. Differences in starch structure, thermal properties, and texture characteristics of rice from main stem and tiller panicles. Food Hydrocoll. 2020, 99, 105341.1-105341.8. [CrossRef]

25. Zhan, X.M.; Zhen, T.S.; Tao, J.H. Study on Application of Texture Analyzer in Quality Evaluation of Rice. Food Sci. 2007, 28, 62-65. (In Chinese)

26. Tangsrianugul, N.; Wongsagonsup, R.; Suphantharika, M. Physicochemical and rheological properties of flour and starch from Thai pigmented rice cultivars. Int. J. Biol. Macromol. 2019, 15, 666-675. [CrossRef] [PubMed]

27. Tan, Y.F.; Li, J.X.; Yu, S.B.; Xing, Y.Z.; Xu, C.G.; Zhang, Q. The three important traits for cooking and eating quality of rice grains are controlled by a single locus in an elite rice hybrid, Shanyou 63. Theor. Appl. Genet. 1999, 99, 642-648. [CrossRef] [PubMed]

28. Zheng, T.; Qi, P.F.; Cao, Y.L.; Han, Y.N.; Ma, H.L.; Guo, Z.R.; Wang, Y.; Qiao, Y.Y.; Hua, S.Y.; Yu, H.Y.; et al. Mechanisms of wheat (Triticum aestivum) grain storage proteins in response to nitrogen application and its impacts on processing quality. Sci. Rep. 2018, 8, 11928.1-11928.13. [CrossRef]

29. Wang, K.; Vilaplana, F.; Wu, A.; Hasjim, J.; Gilbert, R.G. The size dependence of the average number of branches in amylose. Carbohyd. Polym. 2019, 223, 115-134. [CrossRef]

30. Wang, K.; Hasjim, J.; Wu, A.C.; Li, E.P.; Henry, R.J.; Gilbert, R.G. Roles of GBSSI and SSIIa in determining amylose fine structure. Carbohyd. Polym. 2015, 127, 264-274. [CrossRef]

31. Yuryev, V.P.; Krivandin, A.V.; Kiseleva, V.I.; Wasserman, L.A.; Genkina, N.K.; Fornal, J.; Blaszczak, W.; Schiraldi, A. Structural parameters of amylopectin clusters and semi-crystalline growth rings in wheat starches with different amylose content. Carbohyd. Res. 2004, 339, 2683-2691. [CrossRef]

32. Cai, C.; Cai, J.; Man, J.; Yang, Y.; Wang, Z.; Wei, C. Allomorph distribution and granule structure of lotus rhizome C-type starch during gelatinization. Food Chem. 2014, 142, 408-415. [CrossRef]

33. Lu, D.L.; Lu, W.P. Effects of protein removal on the physicochemical properties of waxy maize flours. Starch-Starke 2012, 64, 874-881. [CrossRef]

34. Lal, M.K.; Singh, B.; Sharma, S.; Singh, M.P.; Kumar, A. Glycemic index of starchy crops and factors affecting its digestibility: A review. Trends Food Sci. Technol. 2021, 111, 741-755. [CrossRef]

35. Shinada, H.; Yamamoto, T.; Yamamoto, E.; Hori, K.; Hirayama, Y.; Maekawa, T.; Kiuchi, H.; Sato, H.; Sato, T. Quantitative trait loci for whiteness of cooked rice detected in improved rice cultivars in Hokkaido. Breed. Sci. 2015, 65, 201-207. [CrossRef]

36. Singh, N.; Singh, J.; Kaur, L.; Sodhi, N.S.; Gill, B.S. Morphological, thermal and rheological properties of starches from different botanical sources. Food Chem. 2003, 81, 219-231. [CrossRef]

37. Copeland, L.; Blazek, J.; Salman, H.; Tang, M.C. Form and functionality of starch. Food Hydrocoll. 2009, 23, 1527-1534. [CrossRef]

38. Qi, X.; Tester, R.F.; Snape, C.E.; Yuryev, V.; Wasserman, L.A.; Ansell, R. Molecular basis of the gelatinisation and swelling characteristics of waxy barley starches grown in the same location during the same season. Part II. Crystallinity and gelatinisation characteristics. J. Cereal Sci. 2004, 39, 57-66. [CrossRef]

39. Jane, J.L. Structure of Starch Granules. J. Appl. Glycosci. 2007, 54, 31-36. [CrossRef]

40. Tester, R.F.; Karkalas, J.; Qi, X. Starch-composition, fine structure and architecture. J. Cereal Sci. 2004, 39, 151-165. [CrossRef] 
41. Ahmed, J.; Al-Jassar, S.; Thomas, L. A comparison in rheological, thermal, and structural properties between Indian Basmati and Egyptian Giza rice flour dispersions as influenced by particle size. Food Hydrocoll. 2015, 48, 72-83. [CrossRef]

42. Vamadevan, V.; Bertoft, E. Structure-function relationships of starch components. Starch-Starke 2015, 67, 55-68. [CrossRef]

43. Lindeboom, N.; Chang, P.R.; Tyler, R.T. Analytical, biochemical and physicochemical aspects of starch granule size, with emphasis on small granule starches: A review. Starch Starke 2004, 56, 89-99. [CrossRef]

44. Tamura, M.; Ogawa, Y. Visualization of the coated layer at the surface of rice grain cooked with varying amounts of cooking water. J. Cereal Sci. 2012, 56, 404-409. [CrossRef]

45. Okuda, R.; Ishimura, T.; Kanatani, A. Study on Rice Cooking, Part 1: Effect of Solid Components in the Rice Cooking Liquid on the Rice Grain Surface. Sci. Cookery 2009, 42, 394-403.

46. Martin, M.; Fitzgerald, M.A. Proteins in Rice Grains Influence Cooking Properties! J. Cereal Sci. 2002, 36, 285-294. [CrossRef]

47. Saleh, M.I.; Meullenet, J.F. Effect of protein disruption using proteolytic treatment on cooked rice texture properties. J. Texture Stud. 2007, 38, 423-437. [CrossRef]

48. Thaiudom, S.; Pracham, S. The influence of rice protein content and mixed stabilizers on textural and rheological properties of jasmine rice pudding. Food Hydrocoll. 2018, 76, 204-215. [CrossRef]

49. Saleh, M.I. Protein-starch matrix microstructure during rice flour pastes formation. J. Cereal Sci. 2017, 74, 183-186. [CrossRef]

50. Wang, Y.R.; Zhang, B.; Fan, J.L.; Yang, Q.; Chen, H.Q. Effects of sodium tripolyphosphate modification on the structural, functional, and rheological properties of rice glutelin. Food Chem. 2019, 281, 18-27. [CrossRef]

51. Xia, Y.J.; Wang, J.; Xing, C.R.; Yuan, J. Analysis of Rice Quality in Jianghuai Region. J. Chin. Cereal Oil. Assoc. 2020, 35, 8-13. (In Chinese)

52. Singh, N.; Pal, N.; Mahajan, G.; Singh, S.; Shevkani, K. Rice grain and starch properties: Effects of nitrogen fertilizer application. Carbohyd. Polym. 2011, 86, 219-225. [CrossRef]

53. Keetels, C.; Vliet, T.V.; Walstra, P. Gelation and retrogradation of concentrated starch systems: 1 Gelation. Food Hydrocoll. 1996, 10, 355-362. [CrossRef]

54. Vandeputte, G.E.; Vermeylen, R.; Geeroms, J.; Delcour, J.A. Rice starches. I. Structural aspects provide insight into crystallinity characteristics and gelatinisation behaviour of granular starch. J. Cereal Sci. 2003, 38, 43-52. [CrossRef]

55. Zhu, L.; Bi, S.L.; Wu, G.C.; Gong, B.; Zhang, H.; Wang, L.; Qian, H.F.; Qi, X.G. Study of the migration and molecular structure of starch and protein in rice kernel during heating. Int. J. Biol. Macromol. 2020, 147, 1116-1124. [CrossRef] [PubMed] 